\title{
Enhanced anticancer effects of a mixture of low-dose mushrooms and Panax ginseng root extracts in human colorectal cancer cells
}

\author{
MI SO LEE ${ }^{1}$, MI-SOOK KIM ${ }^{2 *}$, JAE KUK YOO ${ }^{3}$, JI YOUNG LEE ${ }^{1}$, JAE EUN JU $^{1}$ and YOUN KYOUNG JEONG ${ }^{1 *}$ \\ ${ }^{1}$ Radiation Non-clinical Center, ${ }^{2}$ Department of Radiation Oncology, Korea Institute of Radiological and \\ Medical Sciences, Seoul 01812; ${ }^{3}$ Han Kook Shin Yak Pharmaceutical Co., Ltd., Nonsan 33023, Republic of Korea
}

Received February 7, 2017; Accepted June 30, 2017

DOI: $10.3892 /$ or.2017.5796

\begin{abstract}
Worldwide, colorectal cancer is the third most common cancer in men and the second most common in women. As conventional colorectal cancer therapies result in various side effects, there is a need for adjuvant therapy that can enhance the conventional therapies without complications. In this study, we investigated the anticancer effects of combined mixture of the several medicinal mushrooms and Panax ginseng root extracts (also called Amex7) as an adjuvant compound in the treatment of human colorectal cancer. We observed the in vivo inhibitory effect of Amex7 $(1.25,6.25$, and $12.5 \mathrm{ml} / \mathrm{kg}$, oral administration, twice daily) on tumor growth in a mouse model xenografted with HT-29 human colorectal cancer cells. In vitro, at 6,12 , and $24 \mathrm{~h}$ after $4 \%$ Amex 7 treatment, we analyzed cell cycle by flow cytometry and the expression levels of cell cycle progression, apoptosis, and DNA damage repair-related proteins using immunoblotting and immunofluorescence staining in HT-29 cell line. As a result, Amex7 significantly suppressed tumor growth in HT-29 human colorectal cancer cells and xenografts. In vitro, Amex 7 induced G2/M arrest through the regulation of cell cycle proteins and cell death by apoptosis and autophagy. Additionally, Amex7 consistently induced DNA damage and delayed the repair of Amex7-induced DNA damage by reducing the level of HR repair proteins. In
\end{abstract}

Correspondence to: Dr Youn Kyoung Jeong, Radiation Non-clinical Center, Korea Institute of Radiological and Medical Sciences (KIRAMS), 75 Nowon-ro, Nowon-gu, Seoul 01812, Republic of Korea

E-mail: amy3523@kirams.re.kr

Dr Mi-Sook Kim, Department of Radiation Oncology, Korea Institute of Radiological and Medical Sciences (KIRAMS), 75 Nowon-ro, Nowon-gu, Seoul 01812, Republic of Korea

E-mail: mskim@kirams.re.kr

*Contributed equally

Key words: anticancer effect, G2/M arrest, human colorectal cancer, mushroom, Panax ginseng, apoptosis, autophagy, DNA damage repair conclusion, Amex7 enhanced anticancer effects through the induction of G2/M arrest and cell death, including apoptosis and autophagy. Furthermore, Amex7 impaired DNA damage repair. The present study provides a scientific rationale for the clinical use of a combined mixture of medicinal mushrooms and $P$. ginseng root extracts as an adjuvant treatment in human colorectal cancer.

\section{Introduction}

In 2012, colorectal cancer (CRC) was the third most common cancer in men $(746,000$ case, $10.0 \%$ of the total) and the second most common cancer in women $(614,000$ cases, $9.2 \%$ of the total) worldwide (1). The primary treatment for early stage CRC is surgery; however, in more advanced stages of $\mathrm{CRC}$, adjuvant therapy is recommended to increase overall survival rate and prevent recurrence as either local or distant metastasis (2). However, adjuvant chemotherapy harms normal cells, increases treatment resistance, and causes side effects such as vomiting, nausea, diarrhea, and alopecia (3). Several papers have presented candidate drugs from natural products to overcome multidrug resistance in cancer chemotherapy (4-7). Especially, Belcaro et al showed that curcumin reduced semiquantitative evaluation of cancer chemotherapy side effects including vomiting, nausea, diarrhea, and malnutrition (8). Thus, a promising effective and safe strategy to enhance cancer treatment is the development of natural compoundbased cancer therapies.

Natural products have been mainly used as functional foods in order to improve health through activation of physiological functions. In some cases, these have been developed as medicines for several diseases, including cancer, diabetes, and hyperlipidemia (9-11). Among the various natural products, mushrooms and ginsengs are good resources of natural medicines that are non-toxic to normal cells but cytotoxic to cancer cells. Phellinus linteus has been demonstrated to inhibit tumor proliferation by decreasing expression of cyclin B1 and cyclindependent kinases (CDK2, 4, and 6), induce apoptosis through the activation of caspase-2, -3, and -7 and cleaved-PARP in various cancer cells (12), and also suppress tumor growth and pulmonary metastasis in C57BL/6 mice intravenously injected with melanoma cells (13). Furthermore, Inonotus obliquus (Chaga mushroom) has been reported to prevent cell proliferation via the induction of G1 cell cycle arrest in HT-29 human 
colon cancer cells (14). Other mushrooms have been shown to be synergistically adjuvant by exerting immunomodulatory and anti-inflammatory effects (15). Additionally, $P$. ginseng is commonly used by itself or in combination with other medical components. Several studies have demonstrated that the root of $P$. ginseng has anti-inflammatory, anti-diabetes, and anticancer activity (16-18). The previous studies mainly describe a single effect of medicinal mushrooms or $P$. ginseng extract in various cancer cells. However, anticancer effects in a combination of several medicinal mushrooms and/or $P$. ginseng extracts are still unclear.

Our study, which focused on the cell cycle and cell death pathways, investigated whether a combination of seven medicinal mushrooms and $P$. ginseng root extracts (Amex7) enhanced anticancer effects in human colorectal cancer cells when used at a concentration lower than that used in previous studies. Our data may contribute to provide a scientific rationale for the clinical use of the combination of medicinal mushrooms and $P$. ginseng root extracts as an adjuvant compound in human colorectal cancer.

\section{Materials and methods}

Reagents. Anti-Rad51 and anti-excision repair crosscomplementation group 1 (ERCC1) antibodies were purchased from Abcam (Cambridge, MA, USA). Cyclin B1, cyclin A2, cyclin D1, cleaved-PARP (Asp214), phospho-p53 (Ser15), phospho-cdc2 (Tyr15), LC3A/B, sequestosome 1 (SQSTM1)/p62 and cyclin-dependent kinase 2 (CDK2) antibodies were obtained from Cell Signaling Technology (Beverly, MA, USA). Anti-cyclin-dependent kinase 4 (CDK4) and anti-cyclin-dependent kinase 6 (CDK6) were obtained from Bethyl (Montgomery, TX, USA). Cyclin E, Bcl-2, Bcl- $\mathrm{X}_{\mathrm{L}}, \mathrm{Ku} 70, \mathrm{Ku} 80$, anti-p53, survivin, DNA-PKcs, glyceraldegyde-3-phosphate dehydrogenase (GAPDH), horseradish peroxidase (HRP)-conjugated goat anti-rabbit and anti-mouse IgG antibodies were purchased from Santa Cruz Biotechnology (Santa Cruz, CA, USA). Anti-phosphoHistone $\mathrm{H} 2 \mathrm{AX}(\gamma-\mathrm{H} 2 \mathrm{AX}$, Ser139) was provided by Millipore (Billerica, MA, USA). Alexa Fluor ${ }^{\circledR} 488$ goat anti-mouse IgG $(\mathrm{H}+\mathrm{L})$ and Alexa Fluor 594 goat anti-rabbit IgG $(\mathrm{H}+\mathrm{L})$ secondary antibodies were purchased from Invitrogen (Carlsbad, CA, USA). Roswell Park Memorial Institute (RPMI)-1640 medium, fetal bovine serum (FBS), and antibiotics (penicillin and streptomycin) were obtained from Welgene (Daegu, South Korea).

Preparation of the combined mixture of various mushrooms and $P$. ginseng root extracts (Amex7). The combined mixture of seven mushrooms and $P$. ginseng root extracts (also called Amex7) used in this study was obtained from Han Kook Shin Yak Pharmaceutical Co., Ltd. In the first step, $P$. ginseng root was extracted with purified water at $80-100^{\circ} \mathrm{C}$ for $2-3 \mathrm{~h}$. The water extract from $P$. ginseng root was filtered through a $150-\mu \mathrm{m}$ pore size, and then evaporated in a vacuum below $60^{\circ} \mathrm{C}$. In the second step, the extract of $P$. ginseng was mixed with extract powders of Phellinus linteus, Lentinula edodes, Trametes versicolor, Cordyceps militaris, Sparassis crispa, Hericium erinaceum, and Grifola frondosa at $200 \mathrm{rpm}$ for $20 \mathrm{~min}$. The mixture was filtered through a $5-\mu \mathrm{m}$ pore size and

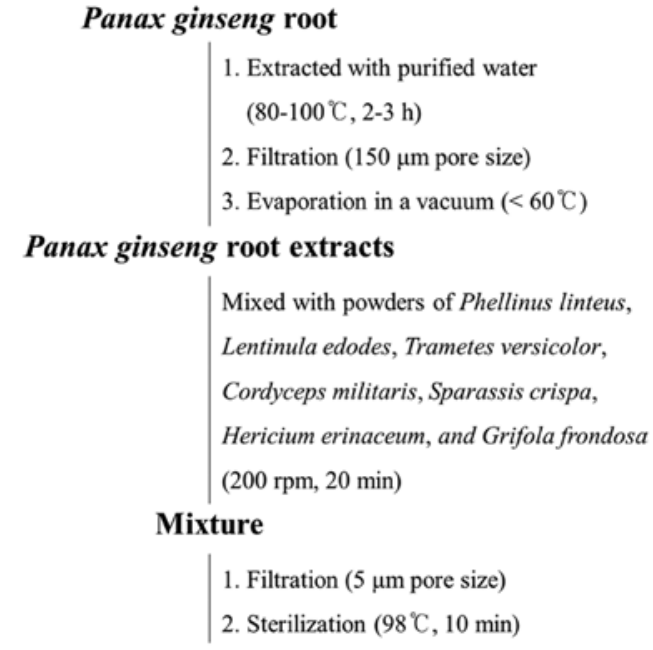

Amex 7

Figure 1. Preparation of a combined mixture of various mushrooms and $P$. ginseng root extracts (Amex7)

Table I. Combined ratio of several compounds in Amex7.

\begin{tabular}{lcc}
\hline Compound & $\begin{array}{c}\text { Combination } \\
\text { percentage }(\%)\end{array}$ & $\begin{array}{c}\text { Volume } \\
(\mathrm{ml})\end{array}$ \\
\hline Phellinus linteus & 1.340 & 1.005 \\
Lentinula edodes & 0.400 & 0.300 \\
Trametes versicolor & 0.400 & 0.300 \\
Cordyceps militaris & 0.400 & 0.300 \\
Sparassis crispa & 0.400 & 0.300 \\
Hericium erinaceum & 0.400 & 0.300 \\
Grifola frondosa & 0.400 & 0.300 \\
Panax ginseng root & 0.130 & 0.098 \\
Pure water & 81.464 & 61.098 \\
Others & 14.666 & 10.999 \\
Total & 100.000 & 75.000
\end{tabular}

subsequently sterilized at $98^{\circ} \mathrm{C}$ for $10 \mathrm{~min}$. Fig. 1 shows the preparation process of Amex7 and Table I lists the combined ratio of several compounds in Amex7.

Cell lines and cell culture. HT-29 human colorectal cancer cells were obtained from the Korean Cell Line Bank (Seoul, South Korea). HT-29 cells were cultured in RPMI-1640 medium supplemented with $10 \%$ FBS, $100 \mathrm{U} / \mathrm{ml}$ penicillin, and $100 \mu \mathrm{g} / \mathrm{ml}$ streptomycin and incubated in an atmosphere of $5 \% \mathrm{CO}_{2}$ at $37^{\circ} \mathrm{C}$.

Drug treatment. Amex7, a combined mixture of several medicinal mushrooms and $P$. ginseng extracts, was kindly provided by Han Kook Shin Yak Co., Ltd. For in vivo experiments, Amex 7 was freshly mixed with drinking water at $1.25,6.25$, and $12.5 \mathrm{ml} / \mathrm{kg}$. For in vitro experiments, Amex 7 was suspended at a concentration of $1,2,4,8$, and $16 \%$ in culture medium. 

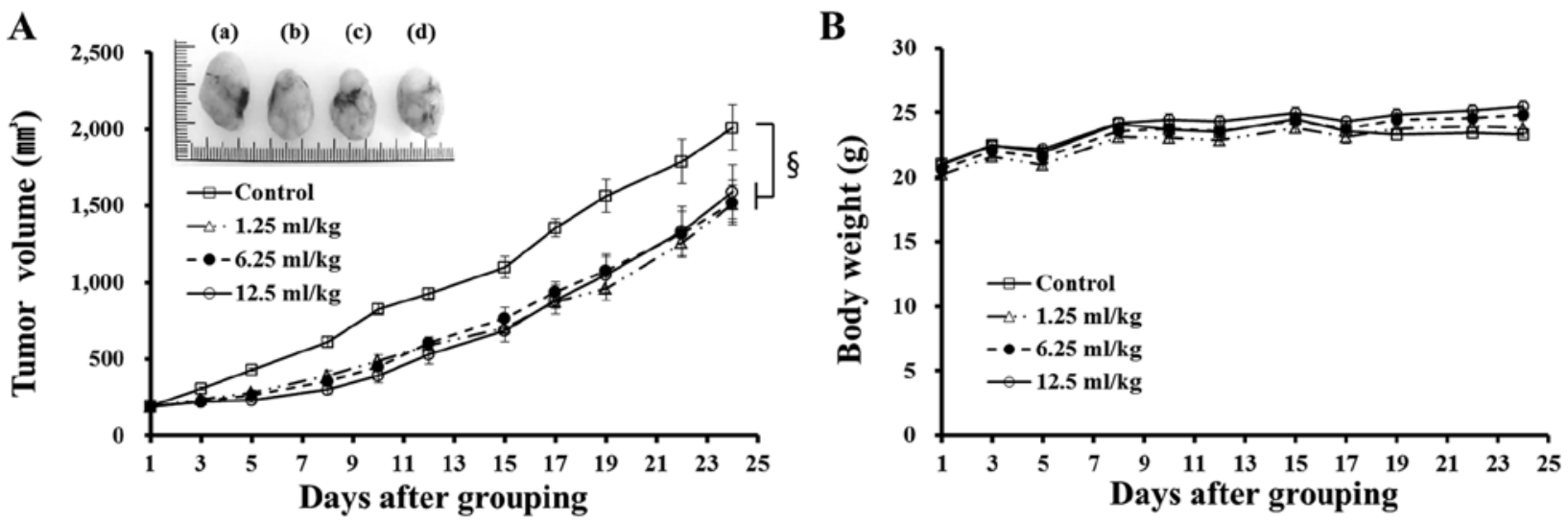

Figure 2. Amex7 inhibites tumor growth in HT-29 human colorectal cancer xenografts. Mice bearing $180-200 \mathrm{~mm}^{3}$ tumors were administered twice daily with Amex7 $(1.25,6.25$, and $12.5 \mathrm{ml} / \mathrm{kg})$ until the mean tumor volume in the control group reached approximately $2,000 \mathrm{~mm}^{3}$. The graphs indicate (A) the tumor volumes and (B) body weights for tumors in the control and three concentrations of Amex7-treated groups. Statistically significant differences are shown: ${ }^{\S} \mathrm{p}<0.001$ vs. control group.

Tumor xenografts in Balb/c nude mice. Balb/c nude mice (5-week-old males) were obtained from Nara Biotech Co. (Seoul, South Korea) and maintained in a laminar airflow cabinet under specific pathogen-free conditions. Mice xenografted with HT-29 cells were obtained by subcutaneous inoculation of $3 \times 10^{6}$ HT-29 cells into the right hind leg. After tumor implantation, we monitored the condition of the animals twice daily and prepared analgesics to minimize animal suffering. When the tumor attained a volume of approximately $180-200 \mathrm{~mm}^{3}$, the mice were randomly divided into four groups $(n=10)$ : a) control, b) $1.25 \mathrm{ml} / \mathrm{kg}$, c) $6.25 \mathrm{ml} / \mathrm{kg}$, and d) $12.5 \mathrm{ml} / \mathrm{kg}$. The tumor volume $(\mathrm{V})$ was calculated using the standard formula: $\mathrm{V}\left(\mathrm{mm}^{3}\right)=\pi / 6 \mathrm{x}$ (shortest diameter) ${ }^{2} \mathrm{x}$ (longest diameter). Mice were euthanized by $\mathrm{CO}_{2}$ inhalation when the average tumor volume of the control group reached $2,000 \mathrm{~mm}^{3}$.

Cell count assay. Cells were seeded in 60-mm culture dishes at $5 \times 10^{4}$ per well and cultured overnight. Then, the cells were treated with serial concentrations of Amex7 $(0,1,2,4,8$, and $16 \%$ ) for 6,12 , and $24 \mathrm{~h}$. At the indicated time points, cells were washed with phosphate buffered saline (PBS), harvested, and immediately stained with $0.4 \%$ trypan blue. Viable cells were quantified using a hemocytometer under an inverted microscope. Cell viability of control group was set at $100 \%$ and the effects of Amex7 on cell viability were expressed relative to the control group.

Cell morphology. Cells were seeded at a density of $3 \times 10^{6}$ cells/dish in a $100 \pi$ dish and incubated for $24 \mathrm{~h}$. The cells were treated with $4 \%$ Amex 7 and incubated for a further 6,12 , and $24 \mathrm{~h}$. The cells were observed by light microscopy (x200) (Motic AE31 microscope, Ted Pella Inc., Redding, CA, USA).

Cell cycle analysis. Cells were treated with 4\% Amex7, incubated for 6,12 , and $24 \mathrm{~h}$, harvested, stained with propidium iodide $(1 \mathrm{mg} / \mathrm{ml})$ according to the manufacturer's protocol, and then analyzed using a FACScan flow cytometer (Becton-Dickinson, Franklin Lakes, NJ, USA). A minimum of 10,000 cells were counted for each sample and data analysis was performed using the CellQuest software.
Immunoblotting. The cells were lysed in radioimmunoprecipitation assay (RIPA) buffer and the proteins were separated using sodium dodecyl sulfate polyacrylamide gel electrophoresis (SDS-PAGE) and transferred to nitrocellulose membranes. The membranes blots were blocked with $5 \%(\mathrm{v} / \mathrm{v})$ skim milk in PBS with $0.1 \%$ Tween-20, incubated with the indicated primary (1:1,000 dilution) and secondary antibodies (1:1,000 dilution), developed using enhanced chemiluminescence (ECL) immunoblotting substrate (Pierce, Rockford, IL, USA), and imaged with the ImageQuant LAS-4000 mini (GE Healthcare, Fairfield, CT, USA). The signal intensity of the bands was measured with the Multi Gauge image analysis software (Fujifilm, Tokyo, Japan).

Immunofluorescence and confocal microscopy. HT-29 cells were seeded on coverslips and grown overnight. After treatment with $4 \%$ Amex7 for 6,12 , and $24 \mathrm{~h}$, the cells were washed and fixed with $4 \%$ paraformaldehyde for $10 \mathrm{~min}$ at room temperature. The cells were washed again, permeabilized in PBS $/ 0.4 \%$ Triton X-100 for $10 \mathrm{~min}$ at room temperature, and blocked in $\mathrm{PBS} / 4 \% \mathrm{FBS}$ for $1 \mathrm{~h}$ at room temperature. The coverslips were stained with primary anti- $\gamma-\mathrm{H} 2 \mathrm{AX}$ (1:500 dilution) antibody, incubated overnight at $4^{\circ} \mathrm{C}$, and then stained with Alexa Fluor 488 Goat anti-Mouse $\operatorname{IgG}(\mathrm{H}+\mathrm{L})$ secondary antibody and DAPI for $1 \mathrm{~h}$ at room temperature. The coverslips were washed and mounted in VectaMount ${ }^{\mathrm{TM}}$ mounting medium (Vector Laboratory, Inc., Burlingame, CA, USA).

Ethics statement. All animal protocols and studies were approved by the Institutional Animal Care and Use Committee (IACUC) of the Korean Institute of Radiological and Medical Sciences (KIRAMS 2015-0058).

Statistical analysis. Results from the in vivo study are expressed as the mean \pm standard error of the mean (SEM) and those from the in vitro study were plotted as the mean \pm standard deviation (SD). The statistical analysis was performed using a Student's t-test and one-way ANOVA followed by Tukey's HSD test using the statistical package for the social sciences (SPSS) software (version 23.0; Chicago, IL, USA). The level of statistical significance was set at a $\mathrm{p}<0.05$. 


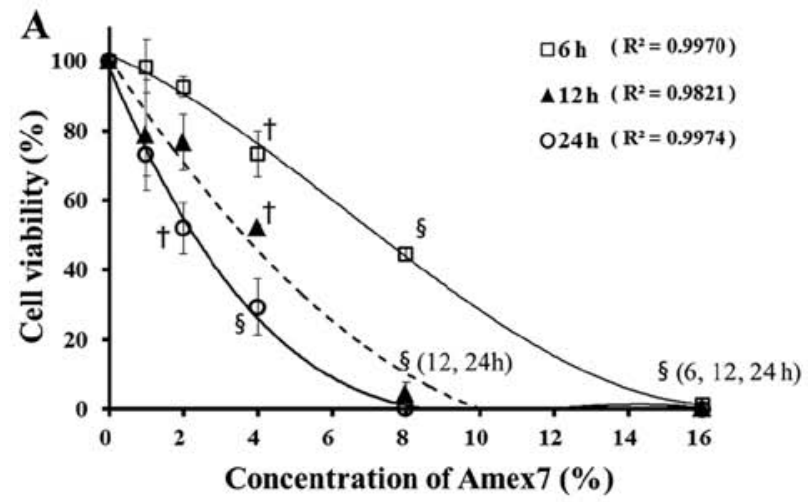

B

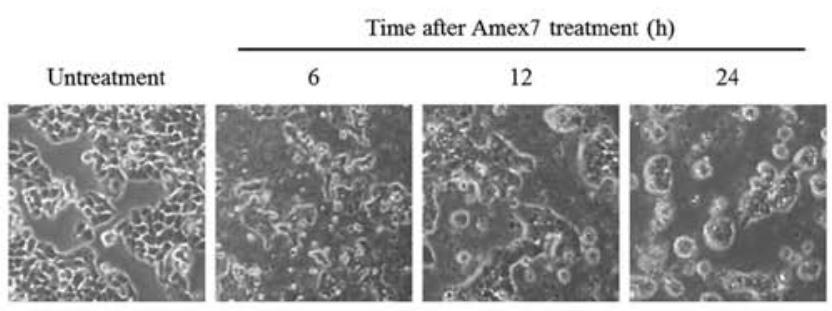

Figure 3. Amex7 decreases cell viability and induced morphological changes in HT-29 human colorectal cancer cells. (A) HT-29 cells were treated with 1-16\% Amex 7 for 6,12 , and $24 \mathrm{~h}$, and then final cell numbers were measured by cell count assay. The graphs indicate the percentage of cell viability in all groups. (B) After treatment of $4 \%$ Amex7 for 6,12 , and 24 h, cell morphology was photographed by light microscopy (x200). Statistically significant differences compared with control are shown: ${ }^{\dagger} \mathrm{p}<0.01,{ }^{\S} \mathrm{p}<0.001$.

A
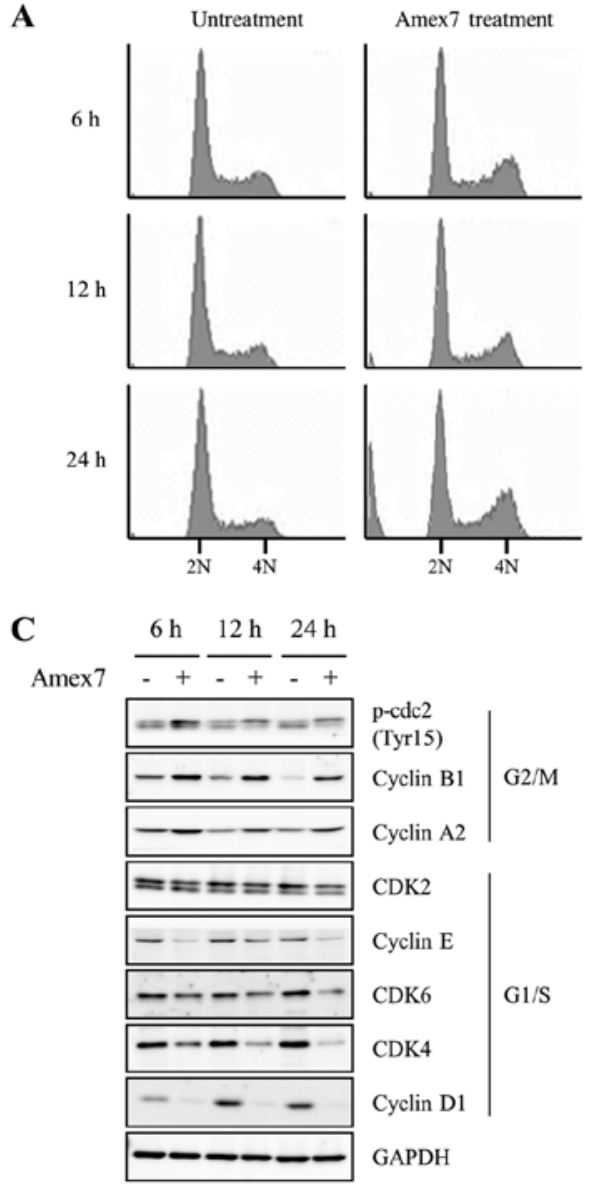

B

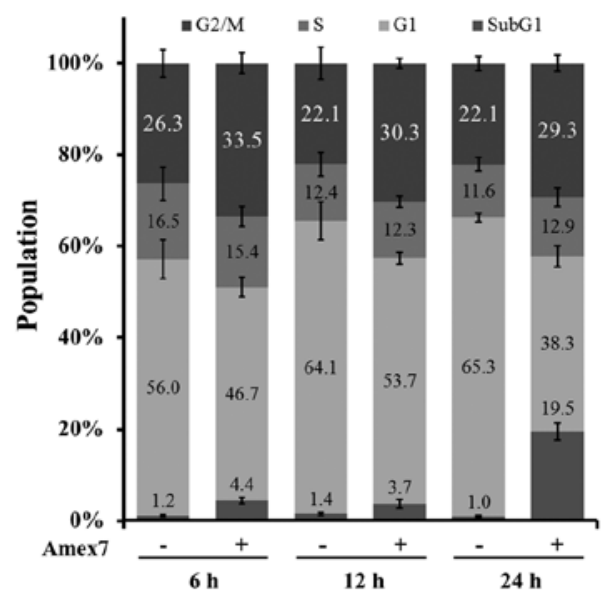

D

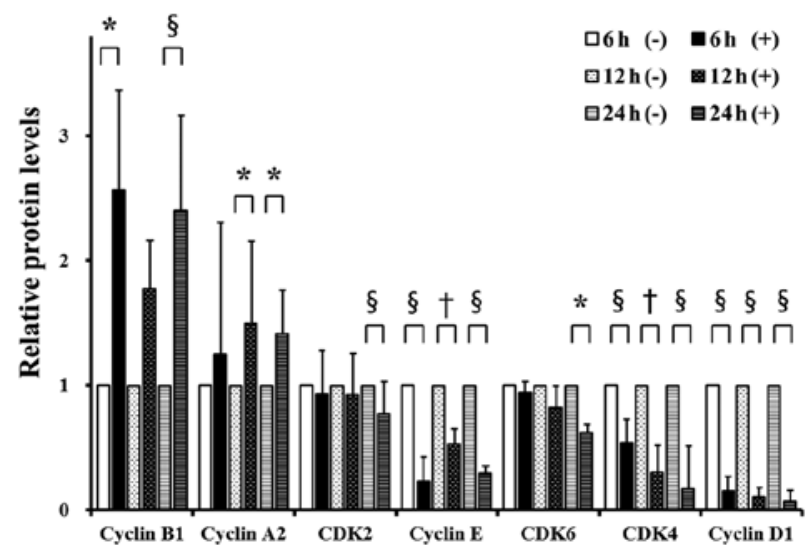

Figure 4. Amex 7 prevents cell cycle progression by regulating cell cycle regulatory proteins. HT-29 cells were treated with $4 \%$ Amex 7 for 6,12 , and $24 \mathrm{~h}$. (A) Cell cycle distribution was analyzed by flow cytometry and (B) was quantified using a FACScan flow cytometer. (C) Expression of G1/S checkpoint regulators (cyclin D1, cyclin E, CDK2, CDK4, and CDK6) and G2/M checkpoint regulators (cyclin A2, cyclin B1, and p-cdc2) were measured by immunoblotting and (D) were quantified using Multi Gauge V3.0 software in HT-29 cells. Densitometric quantification was normalized to GAPDH. (-) indicates the control group and $(+)$ indicates Amex7-treated group. Values are mean $\pm \mathrm{SD}$ of four determination. ${ }^{*} \mathrm{p}<0.05,{ }^{\dagger} \mathrm{p}<0.01,{ }^{8} \mathrm{p}<0.001$ vs. each control group.

\section{Results}

Amex7 significantly inhibits tumor growth in HT-29 human colorectal cancer xenografts. We evaluated the in vivo anticancer effect of Amex7 at various concentrations (1.25, 6.25 , and $12.5 \mathrm{ml} / \mathrm{kg}$ ) in mice xenografted with HT-29 cells. When the mean tumor volume in the control group reached approximately $2,000 \mathrm{~mm}^{3}$, the tumor volume in the mice treated with Amex7 at 1.25, 6.25, and $12.5 \mathrm{ml} / \mathrm{kg}$ was $46.7 \pm 1.5,46.4 \pm 1.2$ and $43.9 \pm 1.8 \%$ smaller, respectively, than the control (Fig. 2A). A significant concentration-independent anticancer effect $(\mathrm{p}<0.001)$ of Amex 7 was observed in the 
A

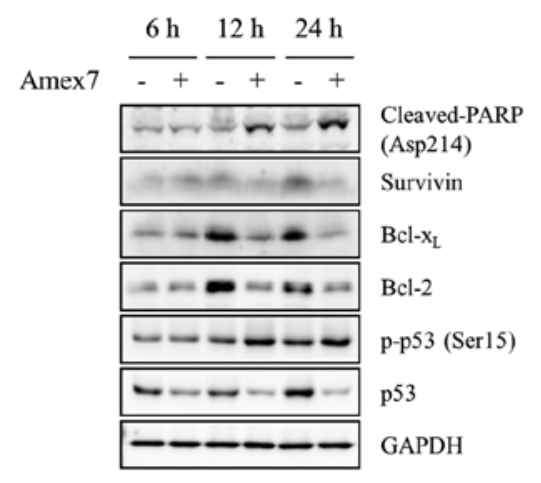

C

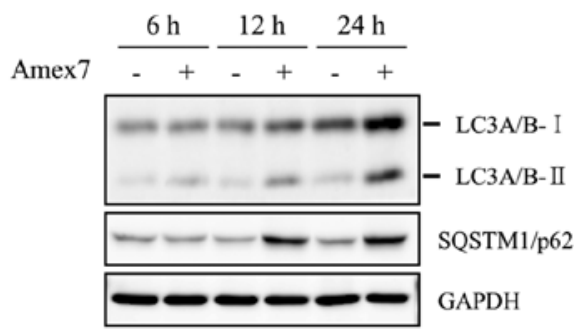

D
B $\quad \square 6 \mathrm{~h} \mathrm{(-)} \quad \mathbf{m} \mathrm{h}(+)$

由12h(-) $\quad$ 圈 $12 \mathrm{~h}(+)$

日24h(-) $\mathbf{2} 24 \mathrm{~h}(+)$
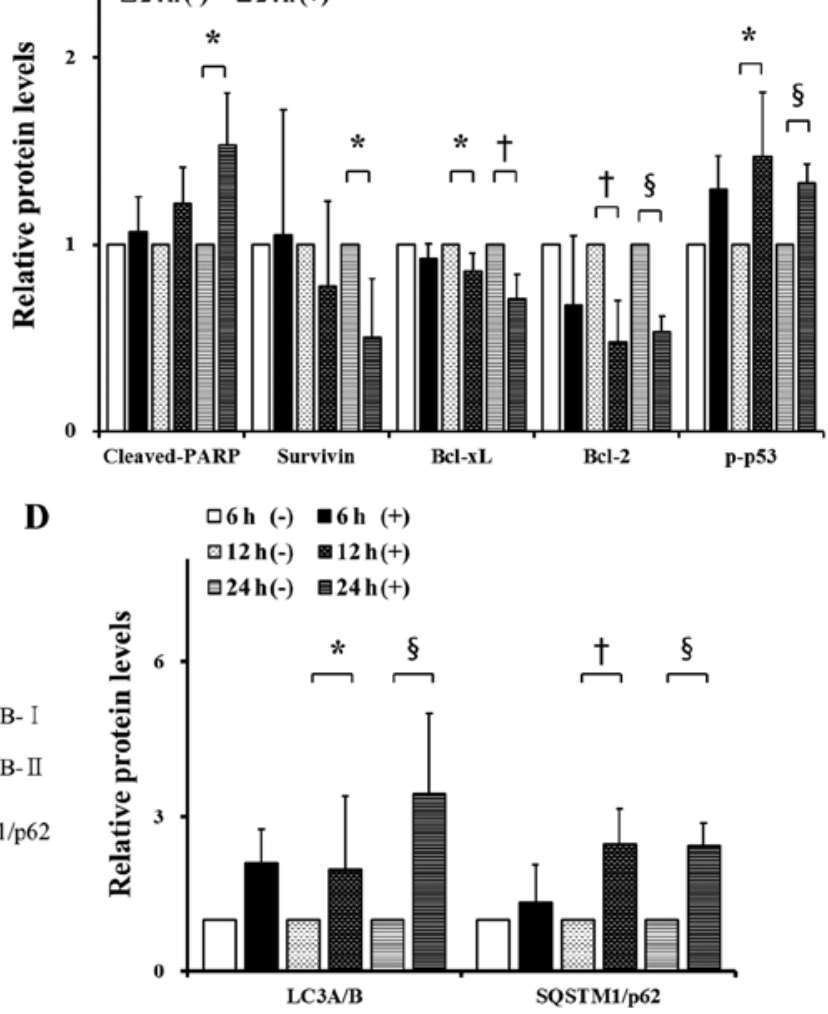

Figure 5. Amex7 induces apoptosis and autophagy in HT-29 cells. Cells were treated with 4\% Amex7 for 6, 12 , and 24 h. To confirm the induction of apoptosis by Amex7, (A) cells from all groups were immunoblotted with p53, phospho-p53 (Ser15), Bcl-2, Bcl- $\mathrm{L}_{\mathrm{L}}$, survivin, and cleaved-PARP (Asp214) and (B) protein levels were quantified using Multi Gauge V3.0 software. In addition, (C) to assess induction of autophagy by Amex7, protein levels of SQTM1/p62 and LC3A/B-II were measured by immunoblotting and (D) protein levels were quantified using Multi Gauge V3.0 software. Densitometric quantification was normalized to GAPDH. (-) indicates the control group and (+) indicates the Amex7-treated group. Values are mean \pm SD of four determinations, ${ }^{\dagger}$ p $<0.01$, ${ }^{\S} \mathrm{p}<0.001$ vs. each control group.

mouse model. Moreover, there were no marked changes in body weight between the control and Amex 7 treatment groups during the administration period of Amex7 (Fig. 2B).

Amex7 decreases cell viability and induces morphological changes in HT-29 human colorectal cancer cells. To assess the anti-proliferative effect of Amex7 on human colorectal cancer cells, we exposed HT-29 cells to serial concentrations of Amex7 (0,1, 2, 4, 8, and 16\%) for 6, 12, and $24 \mathrm{~h}$. By using cell count assay, Amex7 treatment resulted in 99, 93, 73, 45 and $1 \%$ cell viability for $6 \mathrm{~h} ; 79,77,52,4$ and $0 \%$ cell viability for $12 \mathrm{~h}$; and $73,52,29,0$ and $0 \%$ cell viability for $24 \mathrm{~h}$ at 1 , 2, 4, 8, and 16\%, respectively (Fig. 3A). Furthermore, Amex7 changed cell morphology and increased cell aggregations and cellular debris compared with the control cells in timedependent manner (Fig. 3B). Our data showed that Amex7 induces concentration- and time-dependent inhibition of HT-29 human colorectal cancer cell lines.

Amex7 modulates cell cycle progression in HT-29 human colorectal cancer cells. To determine whether the anti-proliferative effect of Amex7 was associated with regulation of the cell cycle, we used flow cytometry to analyze the cell cycle distribution of HT-29 cells in the presence of Amex7. Fig. 4A and $\mathrm{B}$ show that Amex7 significantly decreased the proportion of $\mathrm{G} 0 / \mathrm{G} 1$ phase cells $(\mathrm{p}<0.001)$ and accumulation of $\mathrm{G} 2 / \mathrm{M}$ phase cells compared with the control $(\mathrm{p}<0.001)$. Furthermore, Amex 7 markedly increased the proportion of sub-G1 phase cells at $24 \mathrm{~h}$, but not at 6 and $12 \mathrm{~h}$ after treatment of Amex 7 compared with the control. These results suggested that Amex 7 inhibited cell proliferation by inducing $\mathrm{G} 2 / \mathrm{M}$ phase arrest and apoptosis.

Amex7 induces G2/M arrest by regulating cell cycle regulatory proteins. To further confirm the reduction of cells in the G0/G1 phase and the increase of cells in the G2/M phase, the expression levels of cell cycle regulatory proteins such as cyclin A2, cyclin B1, cyclin D1, cyclin E, phospho-cdc2 (Tyr15), CDK2, CDK4, and CDK6 were examined by immunoblotting. At 6, 12, and $24 \mathrm{~h}$ after Amex7 treatment, the expression levels of cyclin D1, cyclin E, and CDK4, which are involved in G1/S progression, were significantly decreased $(\mathrm{p}<0.01)$ and CDK6 protein level was slightly decreased. Moreover, Amex7 markedly increased cyclin A2 and cyclin B1 protein levels, which are required for $\mathrm{G} 2 / \mathrm{M}$ progression $(\mathrm{p}<0.05)$, but did not change the expression level of phospho-cdc2 (Tyr15) (Fig. 4C and D). In summary, we showed that Amex7 regulated cell cycle progression by significantly reducing G1/S phase-related proteins and increasing $\mathrm{G} 2 / \mathrm{M}$ phase-related proteins.

Amex7 induces apoptosis and autophagy in HT-29 human colorectal cancer cells. In order to identify the induction 
$\mathbf{A}$

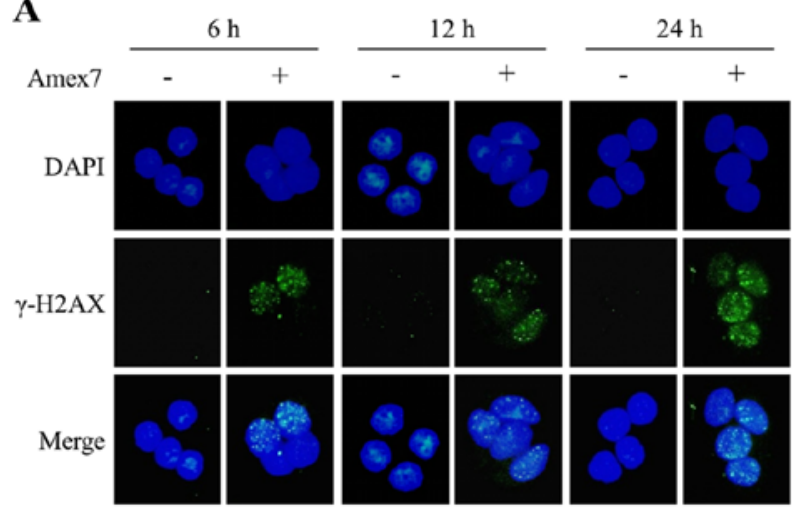

B

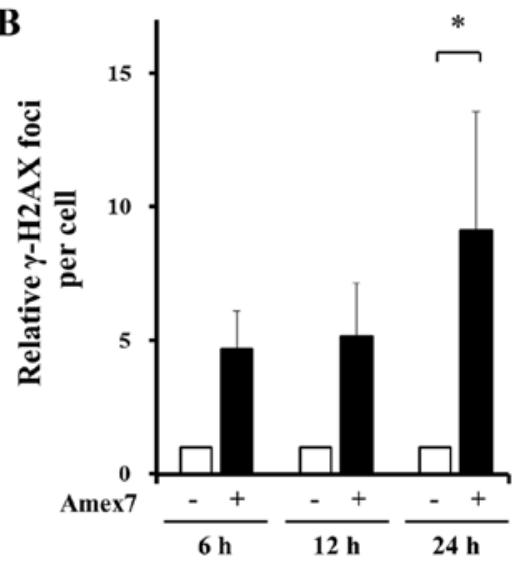

C

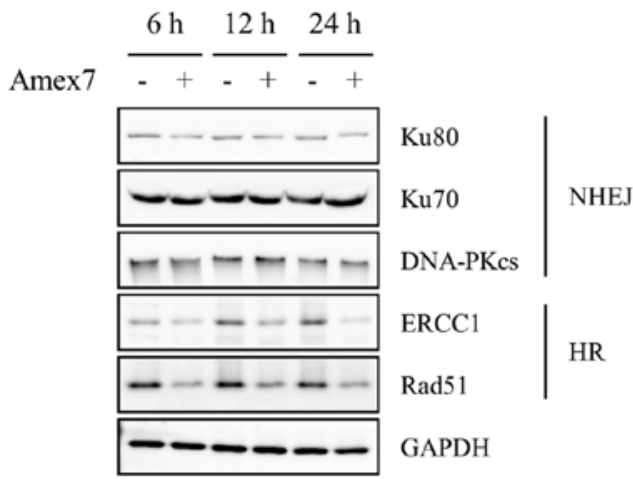

D

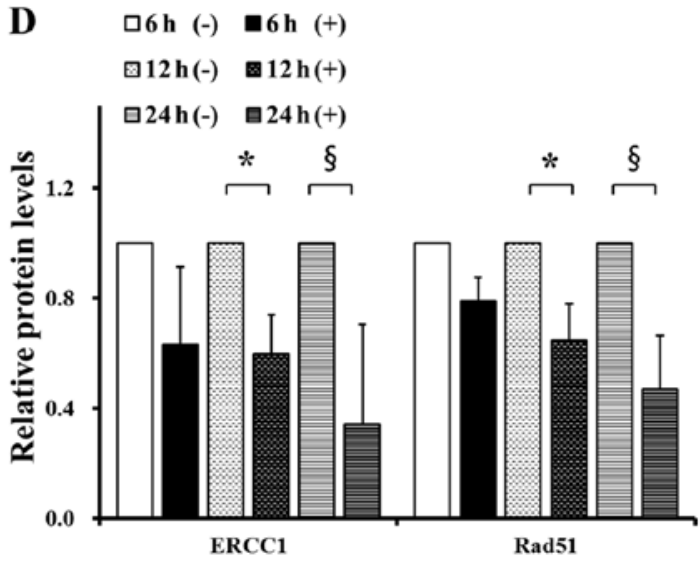

Figure 6. Amex7 regulates DNA damage and repair proteins. HT-29 cells were treated with 4\% Amex7 for 6, 12, and 24 h. To observe DNA damage by Amex7, immunofluorescence staining was performed on cells from all groups. (A) Fluorescence photomicrographs show the merged images of cells stained with $\gamma$-H2AX (green) and counterstained for the nucleus with DAPI (blue). (B) For quantitative analysis, $\gamma$-H2AX foci numbers were counted in 50 cells from randomly captured images. To investigate DNA repair by Amex7, (C) cells from all groups were immunoblotted with Rad51, ERCC1, DNA-PKcs, Ku70, and Ku80 and (D) protein levels were quantified using Multi Gauge V3.0 software. (-) indicates the control group and (+) indicates the Amex7-treated group. Values are mean $\pm \mathrm{SD},{ }^{*} \mathrm{p}<0.05,{ }^{8} \mathrm{p}<0.001$ vs. each control group.

of apoptosis by Amex7, we observed the expression of p53, phospho-p53 (Ser15), Bcl-2, Bcl- $\mathrm{x}_{\mathrm{L}}$, survivin, and cleavedPARP (Asp214) by immunoblotting. At 12 and $24 \mathrm{~h}$ after treatment of Amex7, cleaved-PARP protein (Asp214) was increased and anti-apoptotic proteins, including $\mathrm{Bcl}-2, \mathrm{Bcl}-\mathrm{x}_{\mathrm{L}}$, and survivin, were decreased. In addition, Amex7 treatment for $12,24 \mathrm{~h}$ reduced total p53 protein level, whereas phosphorylated p53 at Ser15 (Fig. 5A and B). Next, to evaluate the induction of autophagy by Amex7, we showed the conversion of the autophagosome protein LC3A/B-I to LC3A/B-II and the expression of SQTM1/p62 using immunoblotting. Starting $12 \mathrm{~h}$ after treatment of Amex7, LC3A/B-II and SQTM1/p62 were consistently induced (Fig. 5C and D). These results suggested that Amex7 induced apoptosis and autophagosome formation in human colorectal cancer cells.

Amex 7 enhances anticancer effect by regulating DNA damage and repair proteins. To investigate the effect of Amex7 on the kinetics of DNA damage and repair, we examined the immunofluorescent staining for $\gamma-\mathrm{H} 2 \mathrm{AX}$ : a marker for DNA strand breaks (DSBs) and stained nuclear DNA with DAPI. The images were analyzed using two (green/blue) fluorescence channels. At $24 \mathrm{~h}$ after treatment of Amex7, we observed an increased number of $\gamma-\mathrm{H} 2 \mathrm{AX}$ foci compared with the control group $(p<0.05)$ (Fig. 6A and B). Next, to evaluate whether Amex7 could affect the DNA repair pathway, we examined the expression of homologous recombination (HR) repair proteins and non-homologous end joining (NHEJ) repair proteins using immunoblotting. As shown in Fig. 6C and D, Amex7 treatment for 12 and $24 \mathrm{~h}$ significantly decreased HR repair proteins, including Rad51 and ERCC1, in HT-29 cells $(p<0.05)$. However, Amex7 did not affect NHEJ repair proteins such as the catalytic subunit of DNA-PKcs, Ku70, and Ku80. These results showed that Amex7 enhanced anticancer effects by increasing DNA damage and reducing HR repair proteins.

\section{Discussion}

Among many functional foods, various types of mushrooms and $P$. ginseng have been reported to possess multiple biological effects, including immunomodulatory, anticancer, anti-oxidative, and anti-inflammatory activity (19-21). In particular, recent studies have focused on the anticancer effect of a concentrated substance extracted from a single medicinal mushroom or $P$. ginseng; however, the biological activity of the combination of multiple medicinal mushrooms and/or $P$. ginseng extracts is still unclear. In our study, we investigated whether a combination of seven medicinal mushrooms 
and $P$. ginseng root extracts (Amex7), when used at lower concentration than in previous studies, enhanced anticancer effects in human colorectal cancer cells, focusing on multiple mechanisms for the anticancer effect.

Several studies have reported that medicinal mushrooms, including $C$. militaris, $P$. linteus, and $L$. edeodes inhibited tumor growth in various human cancer xenografts (22-24), while in vivo anticancer studies of $P$. ginseng root are inconclusive. Consistent with previous studies, we confirmed that Amex7, a combined mixture of medicinal mushrooms and $P$. ginseng root, markedly suppressed tumor growth in HT-29 human colorectal cancer xenografts without a loss of body weight (Fig. 2). Of note, although the amount of extract of seven mushrooms and $P$. ginseng root in Amex 7 was much lower than that used in previous studies, Amex7 significantly inhibited tumor growth in human colorectal cancer xenografts. Therefore, our results indicated that the mixture of a low-dose medicinal mushrooms and $P$. ginseng root extracts enhanced anticancer effects without complication.

Next, we demonstrated the underlying anticancer mechanisms of Amex7 in HT-29 cells. Many studies have reported that the extract of medicinal mushrooms or $P$. ginseng root resulted in cytotoxicity via cell cycle arrest and apoptosis in various human cancer cells. As shown in Fig. 4, Amex7 induced $\mathrm{G} 2 / \mathrm{M}$ arrest by significantly reducing $\mathrm{G} 1 / \mathrm{S}$ phase-related proteins (cyclin D1, cyclin E, CDK2, CDK4, and CDK6) and increasing G2/M phase-related proteins (cyclin A2 and cyclin B1), which was consistent with previous studies $(23,25)$. Especially, the present study showed that Amex7 significantly altered the expression levels of cyclin D1, cyclin E, CDK4, and cyclin B1 compared with the control cells. Additionally, Amex7 induced sub-G1 accumulation, which was suggestive of apoptosis, by reducing anti-apoptotic proteins (Bcl-2, Bcl- $\mathrm{x}_{\mathrm{L}}$, and survivin), increasing apoptotic protein (cleaved-PARP protein (Asp214), and phosphorylating p53 at Ser15 (Fig. 5A and B); these changes were in agreement with previous reports $(26,27)$. Furthermore, we found that Amex7 induced autophagosome formation, as evidenced by LC3A/B-II conversion and SQTM1/p62 accumulation (Fig. 5C and D). Collectively, these data provided that the mixture of medicinal mushrooms and $P$. ginseng root extracts induced G2/M arrest, apoptosis, and autophagy in human colorectal cancer cells.

An interesting observation in our study concerned the effect of Amex7 on the kinetics of DNA damage and repair. Starting early time after Amex7 treatment, Amex 7 consistently induced DNA damage (Fig. 6A and B) and also suppressed the expression of DNA repair proteins, including Rad51 and ERCC1, which play a key role in the DNA HR repair pathway (Fig. 6C and D). Therefore, these results suggested that Amex7 enhances cytotoxicity in human colorectal cancer cells by inducing DNA damage and inhibiting DNA repair.

In conclusion, the combined mixture of mushrooms and $P$. ginseng root extracts inhibited tumor growth, increased cytotoxicity via induction of G2/M arrest, and induced apoptosis and autophagy. Moreover, it enhanced anticancer effect by impairing DNA damage repair. Despite the low-dose of extracts, the mixture enhanced the anticancer effect in human colorectal cancer cells. Accordingly, we suggested a scientific rationale for the clinical application of the mixture of medicinal mushrooms and $P$. ginseng root extracts as an adjuvant compound in treatment of human colorectal cancer that presented no safety concerns.

\section{Acknowledgements}

This study was supported by a grant of the Korea Institute of Radiological and Medical Sciences (KIRAMS), funded by Ministry of Science, ICT and Future Planning, Republic of Korea (no. 1711045548).

\section{References}

1. Ferlay J, Soerjomataram I, Dikshit R, Eser S, Mathers C, Rebelo M, Parkin DM, Forman D and Bray F: Cancer incidence and mortality worldwide: Sources, methods and major patterns in GLOBOCAN 2012. Int J Cancer 136: E359-E386, 2015.

2. Kim R: Treatment of Colorectal Cancer. Cleveland Clinic Foundation, Lyndhurst, OH, 2010.

3. Safdie FM, Dorff T, Quinn D, Fontana L, Wei M, Lee C, Cohen P and Longo VD: Fasting and cancer treatment in humans: A case series report. Aging (Albany NY) 1: 988-1007, 2009.

4. Szakács G, Váradi A, Ozvegy-Laczka C and Sarkadi B: The role of $\mathrm{ABC}$ transporters in drug absorption, distribution, metabolism, excretion and toxicity (ADME-Tox). Drug Discov Today 13: 379-393, 2008.

5. Wu CP, Ohnuma S and Ambudkar SV: Discovering natural product modulators to overcome multidrug resistance in cancer chemotherapy. Curr Pharm Biotechnol 12: 609-620, 2011.

6. Loe DW, Deeley RG and Cole SP: Biology of the multidrug resistance-associated protein, MRP. Eur J Cancer 32A: 945-957, 1996.

7. Penson RT, Oliva E, Skates SJ, Glyptis T, Fuller AF Jr, Goodman A and Seiden MV: Expression of multidrug resistance-1 protein inversely correlates with paclitaxel response and survival in ovarian cancer patients: A study in serial samples. Gynecol Oncol 93: 98-106, 2004.

8. Belcaro G, Hosoi M, Pellegrini L, Appendino G, Ippolito E, Ricci A, Ledda A, Dugall M, Cesarone MR, Maione C, et al: A controlled study of a lecithinized delivery system of curcumin $\left(\right.$ Meriva $\left.^{\circledR}\right)$ to alleviate the adverse effects of cancer treatment. Phytother Res 28: 444-450, 2014.

9. Kang HP, Lee H, Oh TG, Lee KJ, Park SJ, Chung MJ, Kim SU, Lee H, Park JC, Hong SP, et al: The use of health functional foods in gastrointestinal cancer patients. Clin Nutr Res 2: 19-25, 2013.

10. Ballali S and Lanciai F: Functional food and diabetes: A natural way in diabetes prevention? Int J Food Sci Nutr 63 (Suppl 1): 51-61, 2012.

11. Alissa EM and Ferns GA: Functional foods and nutraceuticals in the primary prevention of cardiovascular diseases. J Nutr Metab 2012: 569486, 2012.

12. Sliva D: Medicinal mushroom Phellinus linteus as an alternative cancer therapy. Exp Ther Med 1: 407-411, 2010.

13. Lee HJ, Lee HJ, Lim ES, Ahn KS, Shim BS, Kim HM, Gong SJ, Kim DK and Kim SH: Cambodian Phellinus linteus inhibits experimental metastasis of melanoma cells in mice via regulation of urokinase type plasminogen activator. Biol Pharm Bull 28: 27-31, 2005.

14. Lee HS, Kim EJ and Kim SH: Ethanol extract of Inonotus obliquus (Chaga mushroom) induces G1 cell cycle arrest in HT-29 human colon cancer cells. Nutr Res Pract 9: 111-116, 2015.

15. Guggenheim AG, Wright KM and Zwickey HL: Immune modulation from five major mushrooms: Application to integrative oncology. Integr Med (Encinitas) 13: 32-44, 2014.

16. Park JG, Kang WS, Park KT, Park DJ, Aravinthan A, Kim JH and Cho JY: Anticancer effect of joboksansam, Korean wild ginseng germinated from bird feces. J Ginseng Res 40: 304-308, 2016.

17. Yang Y, Yang WS, Yu T, Sung GH, Park KW, Yoon K, Son YJ, Hwang H, Kwak YS, Lee CM, et al: ATF-2/CREB/IRF-3-targeted anti-inflammatory activity of Korean red ginseng water extract. J Ethnopharmacol 154: 218-228, 2014.

18. Lee CH and Kim JH: A review on the medicinal potentials of ginseng and ginsenosides on cardiovascular diseases. J Ginseng Res 38: 161-166, 2014. 
19. Elbatrawy EN, Ghonimy EA, Alassar MM and Wu FS: Medicinal mushroom extracts possess differential antioxidant activity and cytotoxicity to cancer cells. Int J Med Mushrooms 17: 471-479, 2015.

20. Shin JY, Song JY, Yun YS, Yang HO, Rhee DK and Pyo S: Immunostimulating effects of acidic polysaccharides extract of Panax ginseng on macrophage function. Immunopharmacol Immunotoxicol 24: 469-482, 2002.

21. Wasser SP and Weis AL: Therapeutic effects of substances occurring in higher Basidiomycetes mushrooms: A modern perspective. Crit Rev Immunol 19: 65-96, 1999.

22. Lee HH, Lee S, Lee K, Shin YS, Kang H and Cho H: Anti-cancer effect of Cordyceps militaris in human colorectal carcinoma RKO cells via cell cycle arrest and mitochondrial apoptosis. Daru 23: 35, 2015.

23. Song KS, Li G, Kim JS, Jing K, Kim TD, Kim JP, Seo SB, Yoo JK, Park HD, Hwang BD, et al: Protein-bound polysaccharide from Phellinus linteus inhibits tumor growth, invasion, and angiogenesis and alters Wnt/ $\beta$-catenin in SW480 human colon cancer cells. BMC Cancer 11: 307, 2011.
24. Park SE, Kim J, Lee YW, Yoo HS and Cho CK: Antitumor activity of water extracts from Cordyceps militaris in NCI-H460 cell xenografted nude mice. J Acupunct Meridian Stud 2: 294-300, 2009

25. Shangguan WJ, Li H and Zhang YH: Induction of G2/M phase cell cycle arrest and apoptosis by ginsenoside $\mathrm{Rf}$ in human osteosarcoma MG-63 cells through the mitochondrial pathway. Oncol Rep 31: 305-313, 2014.

26. Youn MJ, Kim JK, Park SY, Kim Y, Kim SJ, Lee JS, Chai KY, Kim HJ, Cui MX, So HS, et al: Chaga mushroom (Inonotus obliquus) induces G0/G1 arrest and apoptosis in human hepatoma HepG2 cells. World J Gastroenterol 14: 511-517, 2008.

27. Li C, Tian ZN, Cai JP, Chen KX, Zhang B, Feng MY, Shi QT, Li R, Qin Y and Geng JS: Panax ginseng polysaccharide induces apoptosis by targeting Twist/AKR1C2/NF-1 pathway in human gastric cancer. Carbohydr Polym 102: 103-109, 2014. 